\title{
"CONTAM QUE HOUVE UMA PORÇÃO DE ENFORCADOS. E AS CAVEIRAS ESPETADAS NOS POSTES": LITERATURA E ORALIDADE NA REVOLTA DOS ESCRAVOS DE CARRANCAS (1833)
}

"They say that there were a lot of hanged people. And the skulls were stuck in poles": literature and orality in the Carrancas Slave Revolt (1833)

"Dicen que hubo mucha gente ahorcada. Y las calaveras clavadas en los postes": literatura y oralidad en la Revuelta de los esclavos Carrancas (1833)

\author{
MARCOS FERREIRA DE ANDRADE ${ }^{*}$
}

https://doi.org/10.1590/S2178-149420210305

'Universidade Federal de São João del-Rei - São João del-Rei (MG), Brasil.

*Professor Associado de História da Universidade Federal de São João del-Rei (marcos.andrade.ufsj@gmail.com)

(D) https://orcid.org/0000-0002-7938-2405

Artigo recebido em 02 de maio de 2021 e aprovado para publicação em 20 julho de 2021. 


\title{
RESUMO
}

0 objetivo deste artigo consiste em discutir a relação entre história, literatura e memória, procurando demonstrar a importância das duas fontes para a construção da representação historiográfica em relação à Revolta de Carrancas (1833). A partir da análise do poema "Levante", de Oswald de Andrade, publicado em 1925 na obra Pau Brasil, procurar-se-á estabelecer um diálogo com os resultados da pesquisa sobre a memória oral da insurreição. Levanta-se a hipótese de que o referido poema está associado à memória senhorial e coletiva da revolta, tendo esta atravessado os séculos, chegando até os dias atuais.

PALAVRAS-CHAVE: História; Literatura; Memória; Revolta de Carrancas.

\begin{abstract}
This article aims at discussing the relationship between history, literature, and memory to demonstrate the importance of two sources that constructed the historiographical representation of the Carrancas Revolt (1833). Based on the analysis of the poem Levante by Oswald de Andrade, published in the work Pau Brasil in 1925, we attempt to establish a dialogue with research results on the oral memory of the insurrection. We explore the hypothesis that the poem is associated with a collective memory of the revolt, as well as the memory derived from the slaveholders' perspective, both having persisted over the last centuries.
\end{abstract}

KEYWORDS: History; Literature; Memory; Carrancas Revolt.

\section{RESUMEN}

El objetivo de este artículo es discutir la relación entre historia, literatura y memoria, tratando de demostrar la importancia de las dos fuentes en la construcción de la representación historiográfica de la Revuelta de Carrancas (1833). A partir del análisis del poema Levante, de Oswald de Andrade, publicado en 1925, en la obra Pau Brasil, se intentará dialogar con los resultados de la investigación sobre la memoria oral de la insurrección. Se plantea la hipótesis de que el mencionado poema está asociado a la memoria señorial y colectiva de la revuelta, que ha atravesado los siglos, llegando hasta nuestros días.

PALABRAS CLAVE: Historia; Literatura; Memoria; Revuelta de Carrancas. 


\section{INTRODUÇÃO}

A relação entre história, literatura e oralidade é muito antiga e transcende ao surgimento tas e intérpretes do Brasil, como Gilberto Freyre e Sérgio Buarque de Holanda, já se utilizavam largamente da literatura como fonte para a escrita da história. Mas foi a partir da década 1980 que a historiografia brasileira produziu obras de grande relevância, influenciadas pelas novas perspectivas da história social, e cultural e a "fonte fecunda" passou a ser cada vez mais objeto de análise historiográfica (Ferreira, 2012: 65). Merece destaque a obra de Nicolau Sevcenko (1982) sobre a Primeira República e a relação entre história e literatura a partir da análise das obras de Euclides da Cunha e Lima Barreto.

No campo dos estudos sobre a escravidão, há muitas aproximações com a literatura para se compreender o passado escravista. Não se trata somente de escritores de romances históricos ou de obras que remontam às memórias ligadas ao cativeiro, mas especialmente daqueles que escreveram suas prosas e seus versos no contexto no qual estavam inseridos. Constituem exemplos desse tipo de análise as interpretações que têm sido feitas sobre as obras de Machado de Assis, além de outros nomes da literatura brasileira e estrangeira (ChaIhoub, 2003; Chalhoub, Neves e Pereira, 2005).

Para o presente artigo, partirei dos estudos clássicos sobre a memória coletiva, como de Maurice Halbwachs, além das considerações acerca da memória subterrânea, de Michael Pollak. Se antes ela era um campo de estudo de outras áreas, especialmente da filosofia e da psicologia, foi a partir de tradição durkheimiana, mas sobretudo de Maurice Halbwachs, que a memória coletiva se constituiu como campo teórico de reflexão e de investigação. Como destaca o autor, a memória individual e a memória coletiva estão profundamente imbricadas, pois esta última "tira sua força e sua duração do fato de ter por suporte um conjunto de homens, não obstante eles são indivíduos que se lembram, enquanto membros de grupo" (Halbwachs, 1990: 51).

Michael Pollak, ao investigar os traumas dos membros de uma associação dos sobreviventes dos campos de concentração de Auschwitz-Birkenau, destaca o papel da história oral ao registrar as memórias subterrâneas dos grupos minoritários e marginalizados em oposição à "memória oficial" ou "nacional" (Pollak, 1989: 4). Embora esteja tratando da memória senhorial que é registrada a partir das memórias individuais e em diálogo com a literatura, gostaria de explicitar por que o conceito de memória subterrânea será empregado para analisar a memória compartilhada relativa à Revolta de Carrancas. Não deixa de ser uma memória subterrânea justamente pelos traumas gerados em determinada região e nos grupos sociais, mas também 
pelos silenciamentos ou daquilo que emerge em relação à violência da escravidão e do acontecimento propriamente dito. Portanto, em certo sentido, o que foi registrado na literatura e nas memórias individuais e compartilhado com distintos segmentos sociais não deixa de ser uma memória subterrânea e coletiva. Outra reflexão importante apresentada pelo autor, em outro texto, trata-se dos "elementos constitutivos da memória individual e coletiva", especialmente quando se trata dos acontecimentos "vividos por tabela", aqueles "vividos pelo grupo ou pela coletividade à qual a pessoa se sente pertencer" (Pollak, 1992: 200). Ou seja, as memórias registradas na literatura e nas cartas da genealogista no século XX e entre os entrevistados no século XXI se reportam a um passado não vivido pelos agentes, mas foram ressignificadas e reelaboradas ao remeterem à insurreição que impactou as elites senhoriais da região e teve grande repercussão na macropolítica do Império. Com as devidas ressalvas feitas anteriormente, acredito que as assertivas do autor podem se aplicar à memória oral da revolta dos escravos de Carrancas, como terei oportunidade argumentar mais adiante.

Os resultados aqui apresentados também se inserem no campo de estudos sobre a memória do cativeiro cujas pesquisas utilizam-se largamente da metodologia da história oral (Alberti, 2007; Meihy e Holanda, 2007) para registrar aspectos do passado escravista recolhidos nos depoimentos das gerações de descendentes dos escravos, também vividos por tabela. São memórias que foram reelaboradas e ressignificadas a partir de vários filtros, que oscilam entre uma visão paternalista e violenta do tempo do cativeiro e reafirmam a importância das práticas comunitárias e dos laços de família, além das múltiplas visões da liberdade e das experiências no pós-abolição (Rios e Mattos, 2005; Weimer, 2010; Rodrigues, 2014). Mas vale ressaltar que há poucos estudos relativos à memória da escravidão que se ocupam de registrar e problematizar a memória senhorial ou das elites que descendem do passado escravista e de como se dão essas batalhas de memória (Mahony, 2007). Nesse sentido, considero que o artigo apresenta uma contribuição particular, embora não se restrinja a esse grupo social. A discussão também se articula com os debates em torno da história pública, na medida em que se trata de passados sensíveis e de disputas de interpretação e de usos do passado. O conhecimento produzido se dá a partir das dimensões dialógica e de alteridade, sendo construído pela interação com os membros das localidades analisadas (Portelli, 2010; Mauad, Almeida e Santhiago, 2016).

Carlo Ginzburg (2007: 7) partiu do mito de Teseu e Ariadne para destacar a importância da relação entre "o fio do relato, que ajuda a nos orientarmos no labirinto da realidade - e os rastros" para a escrita de seus textos e as reflexões sobre a produção historiográfica e a relação entre escrever e contar histórias verdadeiras, ainda que por vezes tenha o falso como objeto. Tentarei fazer o mesmo percurso para analisar a memória senhorial compartilhada 
sobre a revolta dos escravos de Carrancas ao problematizar os relatos presentes na literatura, na memória coletiva e na documentação manuscrita. Espero que, ao final do artigo, não tenha me perdido no labirinto da realidade e consiga, entre o fio e os rastros, oferecer ao leitor uma interpretação do passado escravista brasileiro e demonstrar o quão necessário é refletir sobre ele por meio dessa impressionante história.

\section{"LEVANTE": OSWALD DE ANDRADE E A MEMÓRIA DA REVOLTA DE CARRANCAS}

LEVANTE

Contam que houve uma porção de enforcados

E as caveiras espetadas nos postes

Da fazenda desabitada

Uivam de noite ${ }^{1}$

No vento do mato

(Oswald de Andrade, Pau Brasil, 1925).

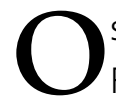
s estudiosos da obra de Oswald de Andrade (1890-1954) e até mesmo de seu filho Rudá de Andrade já chamavam a atenção para o fato de que a obra do modernista "não pode ser desvinculada de sua vida" (apud Candido, 1970: 89). Acrescento que a sua obra, ou pelo menos o poema citado e outros referentes à escravidão, não pode ser compreendida sem considerar a história de seus antepassados paternos de Baependi e de suas ligações estreitas com a família Junqueira e, especialmente, com a história e a memória da revolta dos escravos de Carrancas. A proposta deste artigo consiste em investigar os possíveis vínculos do escritor com a memória oral e a história da revolta e com o passado escravista de seus antepassados paternos, além de defender a hipótese de que a memória senhorial relacionada ao destino dos escravizados que foram mortos no confronto com os proprietários escravistas circulou durante o século XIX, atravessou o século XX, foi registrada pela pena de Oswald Andrade e permanece na memória senhorial e coletiva de distintos segmentos sociais da região até os dias atuais ${ }^{2}$. Mas, antes de estabelecer tais ligações, é preciso traçar um breve resumo da insurreição.

A revolta ocorreu no dia 13 de maio de 1833 e atingiu três fazendas da família Junqueira (Figura 1). 0 levante teve início na fazenda Campo Alegre, com a morte de Gabriel Francisco de Andrade Junqueira, filho de Gabriel Francisco Junqueira, deputado nacional da província de Minas Gerais, de tendência liberal moderada, que se encontrava na corte na referida data, exercendo as atividades no Parlamento. 0 líder Ventura Mina e seus aliados não atacaram a sede da fazenda, pois constataram que ela estava guarnecida, e partiram 


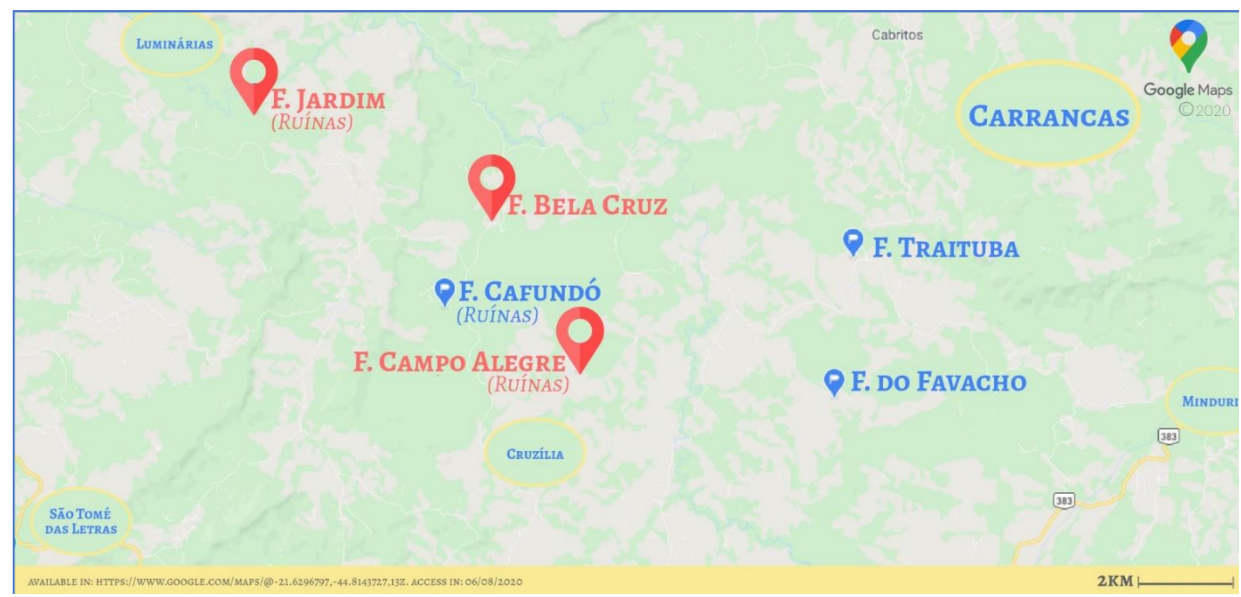

Fonte: Mapa elaborado por Henrique Wellerson Rodrigues, com base no Google Maps.

Figura 1 - Localização das fazendas onde ocorreu a revolta e as divisas atuais dos municípios de Carrancas, Cruzília e São Tomé das Letras.

para a Bela Cruz, de propriedade de José Francisco Junqueira, irmão do deputado. Depois de se reunirem na roça com Joaquim Mina, atacaram-na de surpresa e mataram todos que ali residiam, um total de sete pessoas, utilizando-se de paus, machado, foice e armas de fogo. Um grupo ficou de tocaia à espera do genro de José Francisco, que estava em Campo Alegre. No início da noite, já sabendo do levante, Manoel José da Costa foi à Bela Cruz para socorrer seus familiares e foi morto em uma emboscada assim que cruzou a porteira. Ventura Mina e outro grupo seguiram para a fazenda do Jardim, promovendo o único confronto que ocorreu nessa terceira fazenda. João Cândido da Costa armou dois escravos de confiança e recebeu à bala Ventura Mina e os demais insurgentes. No confronto, Ventura Mina foi baleado e morto. Outros quatro também perderam a vida, a saber: João Inácio, Firmino, Matias e Antônio Cigano. 0 restante do grupo se dispersou, e muitos se embrenharam nas matas e levaram dias para serem capturados. A revolta gerou pânico entre os senhores e as autoridades da região, resultou numa punição coletiva exemplar pouco mais de seis meses depois de decorrido o processo (16 escravos foram condenados à pena de morte e enforcados na vila de São João del-Rei) e teve grande repercussão na macropolítica do Império. Acabou dando origem à lei $n$. 4 de 10 de junho de 1835 (Andrade, 1998/1999: 45-82; 2014: 334-358; 2017: 264-289; Ribeiro, 2005: 43-67; Parron, 2015: 314; Pirola, 2015: 31-88).

A hipótese aqui defendida é a de que o escritor modernista trouxe para o mundo da arte parte da tragédia que marcou profundamente a memória coletiva da região, especialmente da família senhorial e de seus descendentes, e que dela teria tomado conhecimento por 
ter família muito próxima aparentada aos Junqueira pelo lado paterno. Essa memória subterrânea e compartilhada circulou e atravessou o século XIX. Foi parar na literatura modernista de meados dos anos 1920 e permaneceu na memória coletiva tanto dos descendentes da família Junqueira quanto de alguns moradores da antiga região de Carrancas, que também compreende os atuais municípios de Cruzília (MG) e São Tomé das Letras (MG), como demonstrarei mais adiante.

Nenhum dos estudiosos da obra de Oswald de Andrade detalhou a ascendência paterna do escritor, muito menos o parentesco muito próximo com a família Junqueira. Nem mesmo a única biografia, muito bem fundamentada documentalmente, publicada e reeditada por Maria Augusta Fonseca. A partir das memórias e da autobiografia literária Um homem sem profissão, escrita por Oswald, a autora faz algumas referências às visitas do escritor, quase sempre nas férias, aos seus parentes no interior de Minas, mais precisamente no casarão dos Nogueira Andrade, residência dos avós paternos localizada na cidade de Caxambu (MG) (Fonseca, 2007: 37-51).

O ensaísta e crítico literário Antonio Candido, amigo do escritor, analista e prefaciador de suas obras, foi único a fornecer mais detalhes sobre a genealogia paterna de Oswald de Andrade, mas também partindo das memórias e confissões do modernista. Em artigo publicado inicialmente na Folha de São Paulo, em 1982, discutiu sobre a origem do nome do escritor e de sua pronúncia correta, que poderia advir da leitura do romance de Madame de Staël, como o próprio Oswald declarou em suas memórias. Antonio Candido nos informa que a avó paterna de Oswald, Dona Antônia Nogueira Cobra, foi responsável pela escolha do nome do neto e ela era "trineta pelo pai do Capitão-Mor Tomé Rodrigues do Ó, Ilhéu da Madeira, que casou em Guaratinguetá com Maria Leme do Prado e foi pró-homem em Baependi no começo do século XVIII". Dona Antônia foi casada com Hipólito José de Andrade, de outra grande família do Sul de Minas. 0 ensaísta destacou o parentesco com os Junqueira, mas de forma genérica e sem explicitá-lo. Deu destaque apenas à repetição do nome do escritor entre as famílias aparentadas. "Nas famílias Nogueira e Andrade, que eram as de Oswáld pelo lado do pai, e também Junqueira, muito ligada a ambas, encontramos diversos xarás dele, mas (com uma ou outra exceção) na forma vernaculizada" (Candido, 1982: 59).

Gostaria de chamar a atenção para o fato de que a ligação dos avós paternos de Oswald de Andrade vai muito além da preferência ou simplesmente da repetição dos nomes nas gerações seguintes, seja dos Nogueira Andrade, seja dos Junqueira. Para tanto, é importante se reportar aos livros de genealogia que demonstram o entrelaçamento das famílias e como suas relações remontam à época da Revolta de Carrancas e até mesmo antes. Mas, antes disso, vejamos como Oswald de Andrade se referia à sua ascendência paterna no único 
livro de memórias que escreveu, poucos meses antes de falecer, em 1954. A obra Um homem sem profissão: memórias e confissões - 1890-1919 — Sob as ordens de mamãe foi prefaciada por Antonio Candido.

Em Caxambu eu encontrava o panorama familiar. Ali tinha ficado o restante de minha gente paterna, os Nogueira de Andrade, de Baependi. Creio que foi o meu quinto avô, Tomé Rodrigues Nogueira do Ó, quem emigrou de São Paulo, no século XVIII. Era ele casado com uma Leme, o que me fazia passar para o rol dos descendentes dos vicentinos desembarcados nos primórdios da descoberta. Era assim que eu me incluía entre os paulistas de quatrocentos anos e figurava no volume genealógico do racista Silva Leme.

$[\ldots]$

A família prosperou com grande escravaria negra, sendo que meu avô veio, por circunstâncias já referidas, a se arruinar e deixar o latifúndio.

Tenho uma vaga lembrança de minha avó, seca, velha, de óculos e grande leitora. Aliás, atribui-se a ela a origem de meu nome Oswald sem o o final. Ela teria lido Corinne, de Mme. de Stäel, quase sua contemporânea, o que me parece espantoso no fundo provinciano de Minas Gerais. (Andrade, 1976: 30).

Apesar de um pouco longa, a citação é importante para situar o que Oswald registrou em seu livro de memórias. Há uma vinculação de sua ascendência paterna ao tronco das famílias paulistas quatrocentonas e aos Nogueira de Andrade de Baependi, embora não tenha deixado de fazer uma crítica ao genealogista Silva Leme por seu racismo. Também acentuou que a família "prosperou com grande escravaria", mas que a ruína veio, provavelmente, antes da abolição. Como se trata de um livro de memórias e confissões, o modernista não se ateve muito às datas. Mas em outra passagem, ao fazer referência ao seu irmão mais novo, que estava enterrado com os avós paternos no jazigo da família, em Caxambu, registrou que suas "tias trouxeram a escravaria que restava. E foi do aluguel de escravos que a família se alimentou e manteve por algum tempo" (Andrade, 1976: 11). Certamente o escritor estava fazendo referência à memória familiar e ao que deve ter ouvido de seu pai e das próprias tias que foram morar em São Paulo, pois o modernista havia nascido dois anos após a abolição da escravatura. Em outra passagem, mencionou as suas "entrecortadas viagens a Minas", depois que foi matriculado no Colégio São Bento. "Ílamos a Lambari para o Grande Hotel Melo e a Caxambu, onde morava meu avô paterno ainda vivo e uma penca de tias idosas e solteiras" (Andrade, 1976: 28). Portanto, Oswald de Andrade ainda teve oportunidade de conviver com seus avós paternos e a extensa parentela na infância.

Não se trata de estabelecer uma relação automática da história de vida do escritor com o passado escravista em função de sua ancestralidade paterna. Mas também ela não pode ser 
ignorada, e o próprio modernista deixou rastros desse passado na escrita de suas memórias. Por outro lado, é bastante curioso o fato de que Oswald de Andrade em momento algum de sua autobiografia literária tenha explicitado os vínculos de seus ascendentes paternos com a família Junqueira. Mas, com base nos estudos genealógicos e nas listas nominativas de habitantes da década de 1830, em tempos pretéritos, seus ascendentes faziam parte da elite escravista sul-mineira e eram aparentados muito próximos da família Junqueira.

Vejamos. Seu avô paterno, Hipólito José de Andrade, era filho de Maria Rita de Andrade e José Gonçalves Penha. Por sua vez, a sua bisavó paterna era irmã de Inácia Constança de Andrade, que foi casada com Gabriel Francisco Junqueira, deputado por três legislaturas no Parlamento Nacional, que era proprietário da fazenda Campo Alegre e, mais tarde, obteve o título de Barão de Alfenas. Ela também tinha outro irmão que se casou na família Junqueira. Tomás José de Andrade desposou duas filhas de José Francisco Junqueira. A primeira, Antônia Francisca Junqueira, morreu jovem com complicações durante o parto no ano de 1824 (Guimarães, 1990: 202-214, 463-465). Em 1825, casou-se com a segunda filha de José Francisco, Francisca Maximiniano Junqueira. Tomás e Francisca estão entre as primeiras famílias que ocuparam a região de Caldas, no Sul de Minas. É preciso atentar que tanto Gabriel Francisco Junqueira quanto José Francisco Junqueira eram proprietários das fazendas alvos da revolta dos escravos em 1833 (Andrade, 1998/1999, 2017).

Na primeira metade do século XIX, tanto os Junqueira quanto os Andrade possuíam vastas propriedades e escravarias no Sul de Minas (Andrade, 2014: 229-298). A fazenda Bela Cruz, no ano de 1833, tinha 59 cativos. Nas listas nominativas de 1839, a fazenda Campo Alegre contava com mais de 100 escravos $^{3}$. 0 bisavô paterno de Oswald, José Gonçalves Penha, morava próximo da família Junqueira e de duas fazendas importantes da família, Favacho e Traituba. Em 1840, contava 56 anos de idade, já era viúvo e residia com alguns filhos no distrito de São José do Favacho, Baependi, com 47 cativos $^{4}$.

A hipótese que defendo é que, muito provavelmente, a memória da Revolta de Carrancas tenha permanecido e circulado na família de Hipólito José de Andrade e dela tomou conhecimento o seu neto, Oswald de Andrade, pelas várias viagens que fazia para o Sul de Minas nas suas férias e pelo contato que tinha com seus avós e suas tias e, possivelmente, com muitas famílias aparentadas, incluindo os Junqueira, e até mesmo pelo contato que continuou mantendo com as tias depois que foram morar em São Paulo. Também é preciso destacar que uma das fazendas de seus aparentados Junqueira mereceu um registro poético bucólico por parte do escritor. 0 poema "Traituba" é o terceiro da parte "Roteiro das Minas", da obra Pau Brasil (Andrade, 2000: 127). Na Semana Santa de 1924, Oswald, o poeta franco-suíço Blaise Cendrars e vários modernistas paulistas desembarcaram em Minas Gerais e, 
juntos com os modernistas mineiros, percorreram várias cidades e regiões do estado. Essa viagem de "redescoberta do Brasil" ficou registrada em vários poemas da referida obra (Fonseca, 2007: 157-158).

Em 1945, foram reunidos vários livros de Oswald de Andrade em uma única publicação, intitulada Poesias reunidas, da qual constava a obra Pau Brasil. Uma segunda edição crítica, com mais algumas inclusões, foi publicada por Haroldo Campos em 1966. Como constata Diléa Zanotto Manfio, todas as quatro reedições seguintes tomaram por base a edição de 1966. E foi a partir dela e de uma pesquisa detalhada da obra poética do modernista que a autora fez uma análise de seus poemas do ponto de vista da crítica textual. Além das questões próprias do universo da área de Letras, a autora fez uma investigação da obra Pau Brasil e destacou a "busca do passado" pelo autor e o fato de a referida obra poética apontar para "momentos da história social, política e cultural brasileira" (Manfio, 1990: 48). A autora afirma que alguns poemas guardam correlações com o vivido e experienciado pelo poeta, como é o caso do poema "Morro Azul". Trata-se de uma fazenda localizada no interior de São Paulo, em Iracemápolis, que foi visitada por ele e Blaise Cendrars em 1924. Provavelmente o mesmo caso se aplique ao poema "Traituba", pois faz referência à fazenda que pertenceu à família Junqueira, localizada no município de Cruzília, retratada na parte "Roteiro das Minas". A autora destaca ainda que Oswald era um "pesquisador atento" e mergulhava "no passado, na tentativa de entender o presente" (Manfio, 1990: 50). Em relação ao poema "Levante", a autora faz uma análise mais voltada para a crítica textual e os erros tipográficos em reedições subsequentes e opta pela versão da primeira edição, de 1925. Embora não estabeleça nenhum tipo de análise histórica do poema, a leitura que faz das formas verbais "contam" e "uivam" se adequa à perspectiva que também procuro dar ao poema, ou seja, "estabelecem o contraponto: o passado atualiza-se no presente" (Manfio, 1990: 47).

Outros dois estudos literários que esboçaram algum tipo de análise dos poemas relativos à escravidão presentes na obra Pau Brasil apresentam perspectivas de análise bem generalistas ${ }^{5}$. Maria Augusta Fonseca (2004: 135), além de escrever a biografia de Oswald, também realizou uma análise do livro. Ao se deter aos "Poemas da Colonização" referentes à escravidão, sem fazer menção ao "Levante", destacou que eles se reportavam às "marcas trágicas do regime escravista no Brasil". Para Clarissa Loureiro e Antônio Lima (2016: 39), o poema "Levante" representaria a perspectiva do escravo contra o domínio senhorial. Para os autores, "as caveiras espetadas nos postes" poderiam intimidar novos levantes contra os senhores. Mas o "miar das caveiras no vento noturno é a representação da insistência da revolta contra a opressão como uma voz que subterraneamente persiste, apesar de toda a violência colonial como voz que pretende se sobrepor a todas as outras" ${ }^{\text {. }}$. 
Como terei oportunidade de analisar no tópico seguinte, a memória senhorial e coletiva em relação à Revolta de Carrancas circulou e atravessou os séculos XIX e XX e está presente até os dias hoje entre alguns moradores da região de Carrancas, Cruzília e São Tomé das Letras. São narrativas que guardam bastante proximidade do conteúdo expresso no poema "Levante", de Oswald de Andrade. Portanto, trata-se de memórias subterrâneas compartilhadas, "vividas por tabela" e em disputas sobre o acontecimento que serão analisadas a partir do fio e dos rastros constantes das narrativas e das fontes manuscritas.

\section{CABEÇAS ESPETADAS EM MOURÕES DE CERCA: A MEMÓRIA SENHORIAL E COLETIVA DA REVOLTA DE CARRANCAS}

$\mathrm{H}$ á alguns anos, venho desenvolvendo uma investigação acerca da memória do cativeiro nas regiões de Carrancas, Cruzília e São Tomé das Letras, que já resultou em mais de duas dezenas de entrevistas que fazem parte do acervo do Laboratório de Imagem e Som, da Universidade Federal de São João del-Rei ${ }^{7}$. Desse conjunto de entrevistas, escolhi quatro relatos para o presente artigo.

Nos dois primeiros, um dos entrevistados se reporta a um lugar chamado Cabeça Branca, localizado atualmente no município de Cruzília, que seria o local onde teriam sido fincadas as cabeças dos escravos insurretos. Em outros dois, há menção somente ao fato de que as cabeças foram espetadas em mourões com cercas de arame. Por fim, há uma correspondência e anotações de uma genealogista e descendente da família Junqueira que traz informações mais detalhadas em relação ao destino dado às cabeças dos insurgentes, inclusive afirmando que uma delas teria ido parar na propriedade de uma filha de José Francisco Junqueira, que morava na fazenda Chapadão, na região de Caldas, sul de Minas Gerais. Não deixa de ser intrigante como os relatos guardam bastante semelhança com o poema "Levante", de Oswald de Andrade, como será analisado a seguir.

Segundo um dos entrevistados, o senhor Pedro Gonçalves da Rocha, o local ficou conhecido como Cabeça Branca justamente porque alguns dos escravos rebelados teriam sido mortos depois da revolta e as suas cabeças foram colocadas em estacas e, com a ação do tempo, só se viam os crânios esbranquiçados. Daí o nome Cabeça Branca. 0 senhor Pedro Gonçalves da Rocha, atualmente, tem 66 anos, é sitiante, nascido em Cruzília e criado na zona rural, próximo da fazenda Cachoeira. Tem ascendência paterna italiana, pois seu bisavô era italiano e seu avô veio pequeno para o Brasil. Assim como seus pais, trabalhou como empregado em várias propriedades da região. Das recordações de sua juventude, destacou 0 trabalho árduo em várias fazendas, a convivência com os negros que também trabalhavam 
nelas e a lida com as atividades da roça - produção de fubá e polvilho, condução de gado, de carro de boi etc. A primeira entrevista foi realizada em uma área aberta de campo, próxima à fazenda Cachoeira, na zona rural de Cruzília, de onde se podia avistar a localidade denominada Cabeça Branca. Segundo o seu relato, depois do ataque à Bela Cruz e a outras fazendas, a perseguição maior aos escravos ocorreu naquele primeiro local.

Os negros se ajuntou [sic] e veio matando os fazendeiros. [...] Foram em direção a Angaí. Lá pra trás daquela árvore lá, mataram muito negro, dependuram, enfiaram as cabeças deles no mourão da cerca. [...] Nesse lugar lá, por isso que pôs nome de Cabeça Branca por causa de que ficou tudo branquinho a cabeça dos negros. [...] E diz que ficaram assim e aquilo secou, né? E aí depois que o pessoal pôs nome de Cabeça Branca. E porque ninguém mexia naquilo e tinha preconceito de mexer. [...] Naquele tempo todo mundo tinha um medo ${ }^{8}$.

Como o relato do senhor Pedro é bastante rico em detalhes, tive oportunidade de entrevistá-lo uma segunda vez, pouco mais de dois anos depois. Dessa vez, optei por realizar a entrevista justamente no local onde, segundo ele, as "cabeças brancas" dos escravos teriam ficado expostas. Fomos a um local alto, com grandes árvores de paineiras ${ }^{9}$, de onde se podia visualizar a direção das principais fazendas que antigamente pertenciam à família Junqueira (Bela Cruz, Favacho, Traituba, Narciso etc.). Segundo o seu relato, "nessas paineiras aqui, era morada de tropeiro, era ranchamento [sic] de tropeiro, de arrieiro, de cigano. Diz que eles ficavam tudo nesse local aqui. [...] Era caminho que vinha do Favacho, vinha de baixo, sabe? Porque o caminho do Favacho era, antigamente, nessa estradinha aqui" (Figuras 2, 3 e 4).

Quando perguntei novamente por qual razão o local se chamava Cabeça Branca, o senhor Pedro respondeu que "foi depois desses escravos que ficou esse nome, antes era tudo fazenda Traituba, parece". 0 local onde foi realizada a entrevista está bastante próxima aos limites das fazendas Traituba, Favacho e Narciso. Ainda segundo o seu relato, teria ouvido essa história de sua família, do seu pai e de tios já falecidos. E quando comentou sobre o local onde foram deixadas as cabeças dos negros, disse que foi "naquela meia terra lavrada lá [...], naquela estradinha ali já começaram, diz que ali até na fazenda, diz que ali foi o combate dos negros [...], diz que a turma esperaram [sic] eles, sabe? Acho que era o único caminho que eles tinham que passar". Em sua narrativa, os escravos tinham vindo da região de Luminárias, próxima da fazenda Bela Cruz.

Veio vindo, veio vindo, veio juntando, comunicando, aí foi atacando. Aí num certo ponto pra cá que os fazendeiros foi tentando defender. Aqui que foi que defenderam legal, porque aqui conseguiram combater. Aqui, dizem que vinha, saíram aqui, eles vinham acabar com esses Meirelles do Anghay. Do Anghay e outra lá [...] fazenda das Posses ${ }^{10}$. 


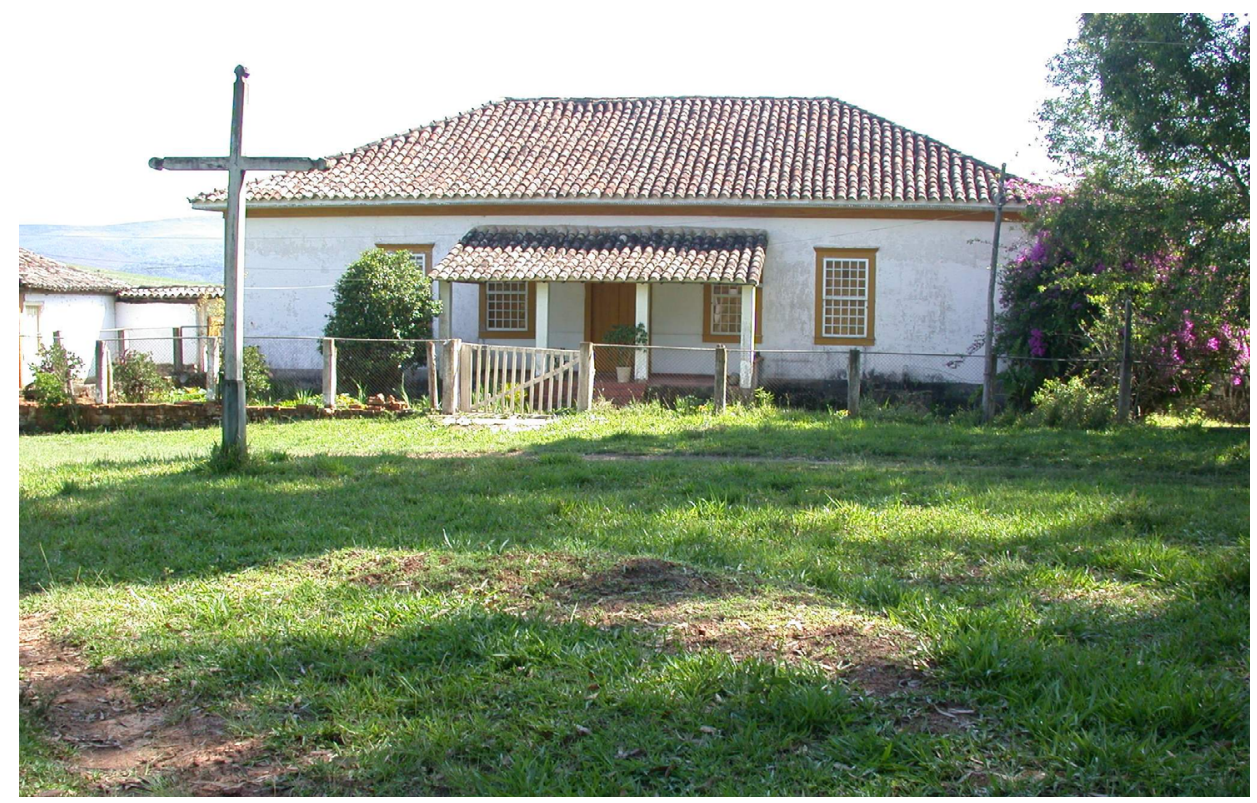

Fonte: Acervo Família Junqueira. Foto de Lilo, nov. 2003.

Figura 2 - Vista frontal da fazenda Bela Cruz - Cruzília (MG).

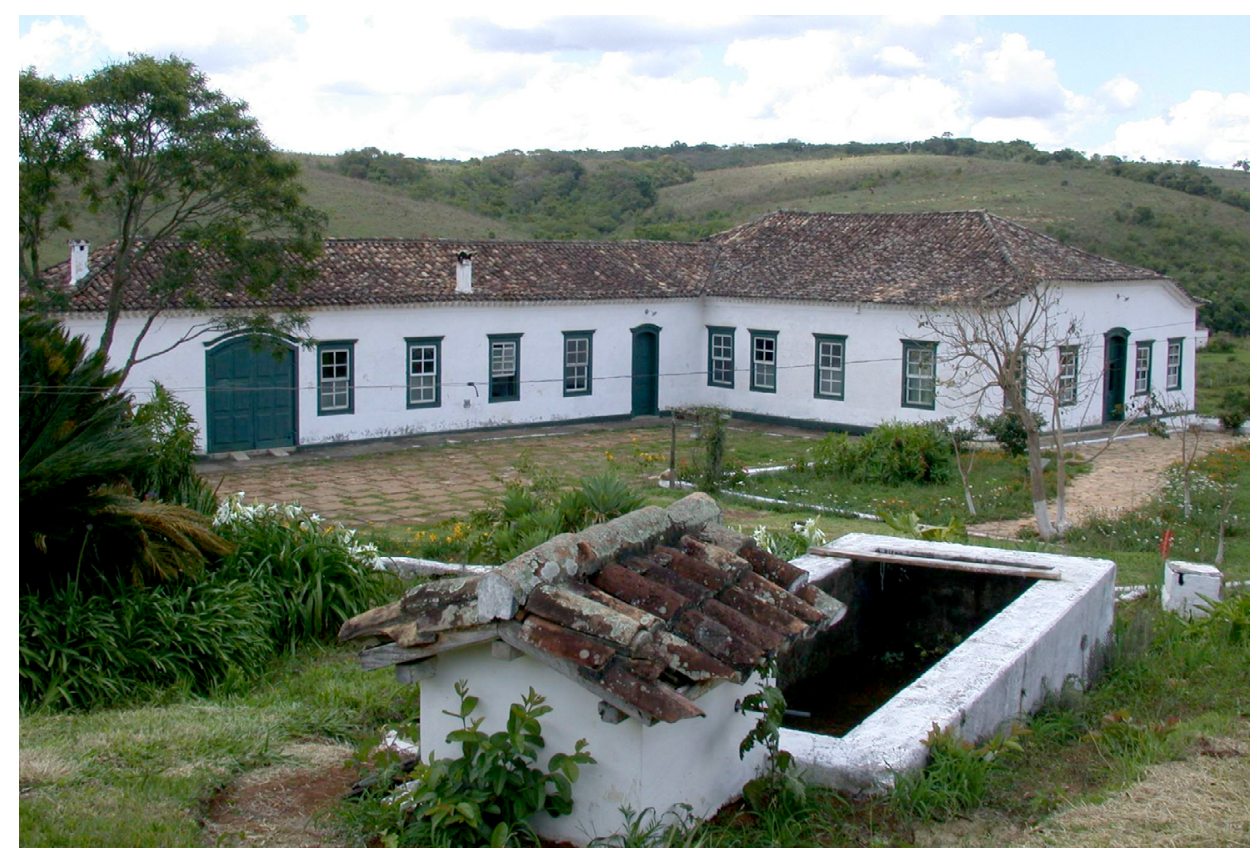

Fonte: Acervo Família Junqueira. Foto de Lilo, nov. 2003.

Figura 3 - Vista frontal da fazenda do Favacho - Cruzília (MG). 


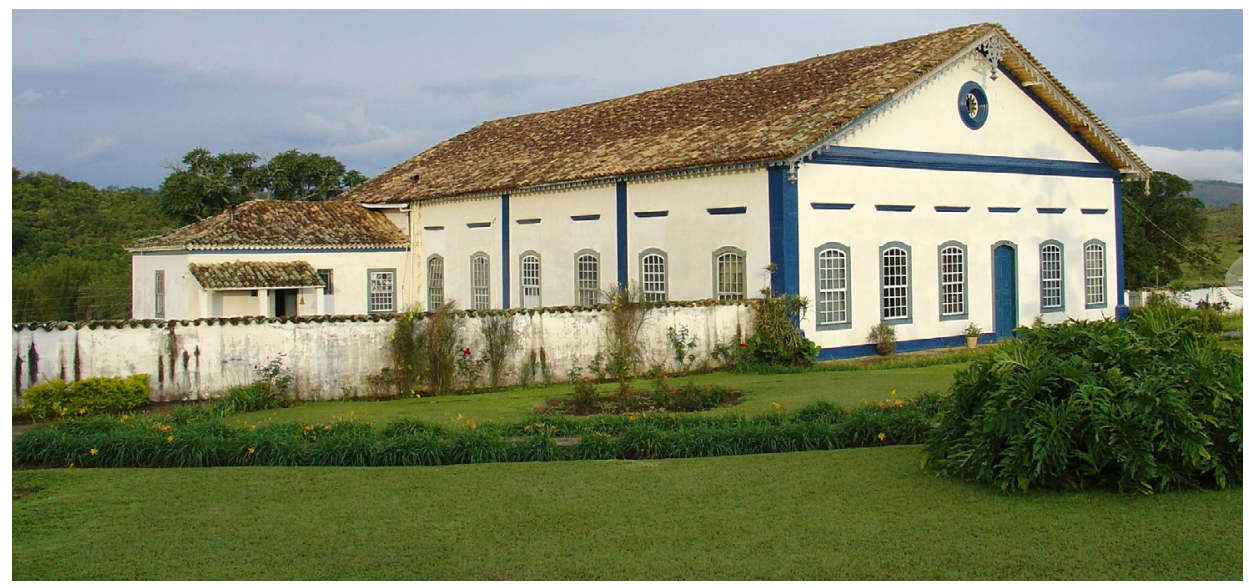

Fonte: Acervo do autor, nov. 2003.

Figura 4 - Vista frontal da fazenda Traituba - Cruzília (MG).

Quando lhe perguntei sobre o número negros mortos e que tiveram as suas cabeças fincadas em mourões, ele respondeu:

Era mais de quarenta negros. Não era pouquinho negro não. Acho que era muito. [...] Os que os fazendeiros conseguiram matar. Assim conta os mais antigos, né? [...] Eu tô falando para vocês o que falaram para mim. Agora eu mesmo não sei por que não foi no meu tempo, né? E nem no tempo do meu pai também e dos meus irmãos não foi, né? ${ }^{11}$.

Em Sobradinho, um distrito de São Tomé das Letras bastante próximo da fazenda Bela Cruz, realizamos duas entrevistas em momentos distintos, mas que também fazem referência ao destino dado às cabeças dos escravizados que foram mortos no confronto.

A primeira foi realizada com o senhor José Maria de Rezende, de idade de 83 anos quando da realização da entrevista. É morador e proprietário da fazenda Sobradinho, vizinha à Bela Cruz. Ele descende da família Ribeiro de Rezende. Segundo seu depoimento, teria ouvido as histórias relativas à revolta quando era criança. "Lá no tempo da escravidão mais antigo deu uma rebelião dos escravos da Bela Cruz contra a outra fazenda do Jardim. Saiu daqui e foi parar lá onde teve o combate deles". Por morar bem próximo à Bela Cruz, seu relato se reporta às duas últimas fazendas atacadas pelos cativos e ao combate na do Jardim. E sobre essa fazenda, relatou que "lá morreram bem escravos, mataram tudo, puseram a cabeça na cerca de arame, nos mourões". Segundo ele, teria ouvido a história dos "moradores mais antigos [...] de Sobradinho. 0 meu pai também contava" 12 .

A segunda entrevista foi realizada com o senhor José Nélio Teodoro, que descende da população afrodescendente da região e fez algumas menções ao tempo do cativeiro. Na épo- 
ca em que foi realizada a entrevista, ele contava com 42 anos de idade e o seu pai, com 70 anos. Segundo José Nélio, a sua família é "dos Teodoros aqui da fazenda dos Junqueiras, da fazenda Floresta". Seu pai "foi nascido e criado ali, trabalhou até aposentar". E os vínculos com os fazendeiros ainda permanecem. Pelo menos é que o deixou transparecer na entrevista. "Agora há pouquinho tempo ele se aposentou; mas, como se diz, está firme na região, é amigo da família até hoje, eles vêm na casa dele, vêm aqui comigo". José Nélio, ou Nelinho, como é popularmente conhecido, é proprietário de uma casa onde tem um espaço dedicado a assar carnes de maneira tradicional e que, segundo ele, remonta ao tempo do cativeiro. É bastante instigante como ele reelabora esse passado e o incorpora à sua atividade atual.

Porque muitas coisas que eram vistas como coisas dos escravos, que hoje para nós se torna benefício. Um dos exemplos, por exemplo: um forno igual a esse de cupim, os escravos, por não terem luz e gás, eles usavam o cupim mais próximo para assar a quitanda, o pão de queijo, até mesmo a caça, que era comum na época — o porco, para assar ${ }^{13}$.

Nelinho procura associar a sua atividade atual ao modo de vida que seria comum também aos escravos e atribui novas ressignificações no presente. "Então, tipo assim, eu uso esse forno na verdade que veio deles, já é uma tradição de família". Quando se reportou ao bisavô paterno, Joaquim Delfino afirmou que "ele também trabalhava nessa fazenda [Floresta]. Era um dos negros de confiança da fazenda e que tinha assim vários conhecimentos que para eles era muito útil". Dentre as habilidades de seu bisavô paterno, destacou que "ele pegava tropa de burro para fazer entrega de queijo em vários pontos, mourões de cerca que tinha que carregar, então ele fazia todos os transportes dentro da fazenda utilizando tropa". Embora não precise as datas e não tenha conhecido o bisavô paterno, somente seu avô, as suas narrativas nos ajudam a pensar nas continuidades de determinadas atividades econômicas e práticas cotidianas que adentraram o século XX e marcaram a memória de seus ascendentes no pós-abolição. A atividade de tropeiro de seu bisavô, o comércio de queijos e o uso de fornos de cupins para assar quitandas e carnes certamente foram atividades que muitos negros, seja na condição de escravizados, seja na condição de libertos, exerceram durante a vigência do cativeiro e no pós-abolição. Em relação ao tempo do cativeiro, ele acredita que seu bisavô paterno não tinha sido escravo pois

estava para nascer [quando] chegou a ordem de que não era para negociar mais. [...] Então são umas das histórias que a família conta e a gente consegue acreditar porque até hoje ainda existe comércios clandestinos, imagina na época que estava para meu bisavô nascer, sem dúvida ainda tinha, era normal que isso existia.

Ao lhe perguntar se os antepassados mais velhos dele faziam alguma referência ao tempo do cativeiro, fez menção a lugares assombrados. E a razão disso: "porque quando um escravo fazia alguma coisa de errado aí eles cortavam a cabeça, por exemplo, e colocava no mourão da 
cerca para de servir de exemplo para os outros. Por isso aquele lugar ficou assombrado" . Curioso que até aquele momento da entrevista, eu não tinha feito nenhuma pergunta relacionada à revolta nem se ele já tinha ouvido falar no local chamado Cabeça Branca. Ele ainda destacou que várias pessoas comentavam essa história.

Ah, é a cava lá da fazenda tal é assombrada mesmo por causa disso. Então você vê que algo que era contado pela família negra, têm muitos brancos da região que conhecem a mesma história da mesma forma. Então você vê assim que não é uma história inventada por medo para fulano não ir ali, é algo que realmente existiu naquele tempo.

É importante destacar, no relato do Nelinho, que a memória da degola de cabeças dos escravos fazia parte da memória coletiva das famílias negras e dos brancos da região. E quando lhe perguntei sobre o nome da fazenda e dessa cava que era considerada o lugar assombrado e sobre a memória das cabeças degoladas e fincadas em mourão, ele afirmou que "a fazenda mais comentada é a fazenda Bela Cruz e Favacho. Isso é as duas mais comentadas" 14. Quando Ihe perguntei se conhecia algum lugar chamado Cabeça Branca, respondeu que o nome não lhe era estranho, mas que não sabia dizer.

É importante situar aqui como as narrativas de Nelinho e o senhor Pedro se diferem, mas ao mesmo tempo se complementam. Como Nelinho e sua família sempre moraram próximos da fazenda Bela Cruz, a memória das cabeças dos escravos fincadas em mourões está associada justamente a essa fazenda, mas também não deixou de mencionar a do Favacho. Provavelmente, a memória familiar de Nelinho esteja associada à fazenda Bela Cruz não só por sempre ter morado próximo dela, mas porque também ali foi o momento mais dramático da revolta e que marcou profundamente não só a memória senhorial, mas também a memória coletiva das famílias afrodescendentes da região. Já a narrativa do senhor Pedro fala do local chamado Cabeça Branca, mais próximo da fazenda do Favacho e bem distante da Bela Cruz, mas também há referência a vala/cava e cerca com mourões onde os escravos degolados durante a revolta tiveram as suas cabeças fincadas e expostas. E sobre o destino dado às cabeças dos insurgentes mortos, as narrativas também se assemelham à do senhor José Maria.

Outra narrativa bastante impressionante está transcrita em uma carta e nas anotações feitas pela genealogista Mariana de Andrade Bueno, já falecida, trineta de José Francisco Junqueira, sobre o destino dado às cabeças dos escravos mortos depois do confronto que se deu na fazenda Jardim, quando a insurreição foi debelada. Segundo ela, nas anotações copiadas do manuscrito do seu tio-avô, Álvaro Ferreira da Costa,

José Francisco Junqueira e sua esposa Antônia Maria de Jesus foram assassinados por seus cinco escravos, motivo porque também foram mortos pelos herdeiros, que ficaram cada um com uma cabeça onde, no Chapadão existia uma cabeça no mourão da porteira da entrada do curral 
da fazenda. [...] Vovô Bié [seu pai], primo Tonico Vilela, Tio Álvaro F. Da Costa e Tio Paulo José Vilela contaram-me que viram esta cabeça fincada no tal mourão; que vovó Emerenciana sendo crente evangélica mandou sepultar a tal cabeça de escravo ${ }^{15}$.

Em outra passagem de suas anotações sobre o levante, a genealogista fez a seguinte afirmação:

[...] os Junqueiras mataram os assassinos (os escravos assassinos) - cortaram suas cabeças e mandaram uma cabeça de lembrança para ser espetada no alto de um pau para que os demais escravos nunca mais se atrevessem a cometer tão nefando crime. Obs. Nossa ancestral Ana Francisca Junqueira trouxe uma cabeça dessas, que ficou espetada bem em frente à fazenda do Chapadão ${ }^{16}$.

Ana Francisca ficou conhecida na memória familiar como a Ana do Chapadão. Era filha de José Francisco Junqueira, morto pelos escravos na fazenda Bela Cruz, em 1833, e bisavó da genealogista ${ }^{17}$. A fazenda do Chapadão, atualmente em ruínas, está localizada localizada na região de Caldas, extremo sul de Minas Gerais, quase na divisa com o estado de São Paulo.

Uma narrativa recorrente na memória familiar, presente também em obras de de historiadores locais e genealogistas (Pelúcio, 1942: 231; Mattos, 2004: 97) e entre os moradores das localidades de Carrancas e Cruzília, é que uma criança teria sobrevivido ao massacre da Bela Cruz. Teria sido salva por uma escrava de confiança depois de escondê-la dos insurgentes. Nos autos não há qualquer menção a respeito. Todos os membros da família senhorial daquela propriedade foram mortos por alguns dos escravos que participaram da revolta (Andrade, 1998/1999, 2017).

Não deixa de ser surpreendente a coincidência da memória histórica com a memória registrada nas cartas de Mariana de Andrade Bueno, pelo menos em relação ao número de escravos mortos. Isso talvez se explique porque a genealogista possuía uma cópia de uma correspondência redigida por um juiz de paz da época e que fazia referência à insurreição ${ }^{18}$. Não sei precisar se ela chegou a ter acesso aos autos, o documento mais importante da Revolta de Carrancas, embora, na sua correspondência pesquisada, existam algumas anotações com o seguinte título: "O processo do massacre da Bela Cruz". A existência do processo-crime foi citada pela primeira vez pelo cônego José Antônio Marinho no livro que escreveu sobre a revolta liberal de 1842. Segundo o historiador do movimento, que lutou do lado dos liberais, os Junqueira teriam sido novamente ameaçados e lembrados da tragédia ocorrida nove anos antes. Mencionou que a família do deputado "foi quase toda massacrada pelos escravos, que em uma das fazendas não deixaram vivo nenhum menino de peito; e existem nos cartórios da cidade de S. João d'El-Rei provas irrefragáveis" (Marinho, 1844: 24) ${ }^{19}$. 
Nas pesquisas que realizei, a partir dos autos-crime, cinco cativos foram mortos depois do único confronto ocorrido na fazenda Jardim, quando Ventura Mina e seu grupo tentaram atacá-la. João Cândido da Costa e dois escravos de confiança armados puseram fim ao levante e mataram o líder Ventura Mina. Mais quatro cativos foram mortos posteriormente, a saber: João Inácio, Firmino, Matias e Antônio Cigano (Andrade, 1998/1999: 64-65). Mas não há nenhum registro do sepultamento deles e nenhum indício de que suas cabeças tivessem sido decepadas e fincadas em paus, postes ou mourões. Só há menção ao caso de um escravo, mas sem indicação do nome, que, "por julgar-se morto", foi "atirado por um pedestre ou guarda, lançou-se ao rio" 20 .

A liderança de Ventura Mina foi bastante destacada, seja pelos companheiros de cativeiro, seja pelos livres. No libelo acusatório, ele foi descrito como um escravo que tinha um "gênio fogoso e ardente, era empreendedor, ativo, laborioso, tinha uma grande influência sobre os réus e estranhos de quem era amado, respeitado e obedecido"21. Alguns cativos da Campo Alegre e da Bela Cruz alegaram em sua defesa que participaram do levante "por medo", depois de terem sido ameaçados de serem degolados por outros escravos armados de foice e pelo líder Ventura Mina22. Nos autos, há pelo menos um registro de decapitação. Segundo o corpo de delito, Ana Cândida da Costa, viúva de Francisco José Junqueira, foi morta a golpes de foice e cacetadas, e a cabeça não se achava "unida ao corpo" 23.

Para crimes dessa natureza, as execuções das penas e os rituais públicos e exemplares constituíam monopólio do Estado. No Antigo Regime, a morte natural diferia do sentido dado aos tempos atuais. Era uma morte violenta e com exposição pública de parte dos corpos, como as de Felipe dos Santos e Tiradentes, mas também de muitos negros quilombolas que tinham as cabeças degoladas para servir de pagamento aos capitães do mato na caça aos escravos fugidos (Campos, 1992:142). A morte natural na forca ocorreu para os escravos africanos e crioulos de Carrancas. Dezesseis foram exemplarmente punidos e levados ao patíbulo na rua da Forca, na vila de São João del-Rei: 12 foram enforcados no início de dezembro de 1833 e os últimos quatro, em abril de 1834 (Andrade, 2017: 280). Segundo os artigos 113 e 192 do Código Criminal de 1830, os escravos cabeças de insurreição e aqueles que cometessem o crime de homicídio em circunstâncias agravantes, respectivamente, no grau máximo eram punidos com a pena de morte por enforcamento ${ }^{24}$. E, no caso de Carrancas, ela foi seguida praticamente à risca.

Mas, tomando por base a literatura e a memória senhorial e coletiva, Ventura Mina, João Inácio, Firmino, Matias e Antônio Cigano teriam tido as suas cabeças decepadas e colocadas em estacas para servirem de exemplo aos outros escravos da região? "E as caveiras [ficaram] espetadas nos postes da fazenda desabitada" e "uiva[va]m de noite", como na des- 
crição do poema de Oswald de Andrade? E o local denominado Cabeça Branca seria mesmo uma referência às suas cabeças que ficaram expostas até se decomporem e ficarem somente os crânios esbranquiçados? Os Junqueira teriam feito um justiçamento à revelia da lei e do Código Criminal da época e espetado as cabeças dos cinco escravos mortos no confronto "para que os demais [...] nunca mais se atrevessem a cometer tão nefando crime" ? Não é uma hipótese a ser descartada, se considerarmos o terror causado pela ação dos cativos e pela forma violenta como foram mortos vários membros da família senhorial. Há que se fazer uma investigação mais detalhada nos registros de óbitos para ver se há alguma menção aos referidos escravizados assassinados depois do confronto com João Cândido da Costa e de iniciada a repressão aos insurretos e se tiveram um enterro católico. Em relação à família senhorial, houve o registro dos mortos e de seus sepultamentos na matriz de São Tomé das Letras, nas fontes paroquiais, três dias após a revolta (Andrade, 2017: 266; Mattos, 2004: 96-97). Conforme já referido, nos autos também foram registradas as execuções das sentenças de enforcamento dos dezesseis escravos condenados à pena máxima.

É preciso assinalar que a memoria senhorial e coletiva que permanece na região pesquisada é a do justiçamento realizado por parte da família Junqueira e a expiação pública das cabeças dos escravos mortos no confronto e de uma sobrevivente, membro da família senhorial. Mas não há qualquer menção aos nomes dos cativos que foram mortos e que, porventura, teriam sido degolados. Também não há alusão aos enforcamentos dos escravos realizados na vila de São João del-Rei e tampouco aos nomes dos membros da família Junqueira mortos nas fazendas Campo Alegre e Bela Cruz. Por outro lado, há referência nos autos sobre a decapitação de um dos membros da família senhorial e das ameaças de degola que teriam sido feitas por Ventura Mina aos insurgentes. As lembranças e os esquecimentos são elementos constitutivos da memória e podem ser intencionais ou não. E, como tais, precisam ser problematizados. Como destaca Jacques Le Goff (2003: 422), "tornar-se senhores da memória e do esquecimento é uma das grandes preocupações das classes, dos grupos e dos indivíduos que dominam as sociedades históricas". Por isso, os "esquecimentos e silêncios da história são reveladores destes mecanismos de manipulação da memória coletiva". Ou, como acentua o antropólogo Michel-Rolph Trouillot (2016: 101) na releitura que imprime da Revolução Haitiana, ao desenterrar os silêncios "e a subsequente ênfase do historiador sobre o significado retroativo de eventos até então negligenciados", exige não só uma investigação a partir de um conjunto diversificado de fontes, "mas também um projeto vinculado a uma interpretação". Ao que tudo indica, o resultado sangrento da Revolta de Carrancas, que culminou na morte de 21 escravos (somados os que foram mortos durante a insurreição e os enforcados) e de nove membros da família Junqueira, marcou e traumatizou profundamente a memória senhorial 
e coletiva da região. A memória que permanece na literatura e nos relatos é a da punição exemplar dos escravos insurretos, seja a dos enforcamentos ou a das suas cabeças fincadas em mourões, mas com algumas nuances tanto pelo que emerge quanto pelo que é silenciado.

Não deixa de ser impressionante como essas memórias subterrâneas, compartilhadas e vividas por tabela se relacionam e estão diretamente associadas à revolta. Como pude destacar, o fio e os rastros dessa história estão presentes na literatura, possivelmente extraídos das memórias familiares da ascendência paterna de Oswald de Andrade com os Junqueira, das memórias individuais dos senhores Pedro Gonçalves da Rocha, José Maria de Rezende, José Nélio Teodoro e da carta e das anotações da genealogista Mariana de Andrade Bueno. Trata-se de memórias coletivas que remontam ao tempo do cativeiro e à violência da escravidão. Nesse sentido, há uma aproximação entre a memória histórica e a memória coletiva, que envolvem sujeitos de classes sociais distintas, mas que confrontam o passado e disputam na memória histórica o lugar dos vencedores.

\section{CONSIDERAÇÕES FINAIS}

e compararmos os relatos individuais, podemos constatar que eles se reportam às memó-
rias compartilhadas que traumatizaram a família e as gerações subsequentes e que foram registradas não só na literatura e na pena de Oswald de Andrade, mas também na memória coletiva da região de Carrancas, incluindo a de um membro de uma família de afrodescendentes. Se assim não fosse, não teria encontrado tanto o fio quanto os rastros desse passado nas narrativas de indivíduos pertencentes a distintos segmentos sociais, e não somente dos descendentes da família Junqueira. Trata-se também de acontecimentos vividos por tabela, pois o passado recordado não foi experienciado pelos entrevistados. São memórias geracionais que foram sedimentadas, reelaboradas e ressignificadas por mais de um século e meio. Circularam entre os descendentes da família senhorial. Foram registradas em cartas e na literatura e ainda permanecem vivas, de alguma maneira, na memória de alguns moradores da localidade onde ocorreu o levante dos escravos. São memórias compartilhadas por diferentes segmentos sociais e que também descortinam as disputas em torno do acontecimento.

Gostaria de encerrar o artigo remetendo às reflexões de Jeanne Marie Gagnebin em relação à tarefa ética e igualmente psíquica do historiador. Os escritos produzidos por nós "ajudam a enterrar os mortos do passado e a cavar um túmulo para aqueles que dele foram privados. Trabalho de luto que nos deve ajudar, nós, os vivos, a nos lembrarmos dos mortos para melhor viver hoje". Creio que isso se aplica, especialmente, a Ventura Mina, João Inácio, Firmino, Matias e Antônio Cigano, que não sabemos se foram sepultados nem qual destino foi dado aos seus 
corpos. Portanto, recontar essa história a partir do fio e dos rastros, esquecimentos, silenciamentos e fragmentos da memória em suas múltiplas formas e dos documentos manuscritos consiste em compreender que a "preocupação com a verdade do passado se completa na exigência de um presente que, também, possa ser verdadeiro" (Gagnebin, 2006: 47).

\section{NOTAS}

1 Na versão publicada a partir de 1945 e nas seguintes, o terceiro verso vem grafado da seguinte forma: "Miavam de noite". Optei por seguir a edição da obra Pau Brasil de 1925, corrigida pelo próprio autor no exemplar que presenteou ao amigo Mário de Andrade, conforme constatou Diléa Zanotto Manfio na análise crítica textual que realizou da obra do modernista. Segundo a autora, "não resta dúvida que a expressão correta é 'Uivam de noite'. Por outro lado, 'Uivam' dá ao verso mais força poética, além de adequar-se com maior eficácia ao contexto do poema" (Manfio, 1990: 47).

2 Agradeço ao escritor e poeta Caio Junqueira Maciel a indicação desta obra de Oswald e dos poemas "Levante" e "Traituba", que fazem parte dos conjuntos "Poemas da Colonização" e "Roteiro das Minas", respectivamente, depois de uma conversa que tivemos ao Ihe relatar que a memória relativa ao local chamado Cabeça Branca está associada à memória da Revolta de Carrancas.

3 Arquivo Público Mineiro. Listas nominativas de habitantes de 1838/1840 para o distrito de São Tomé das Letras. Banco de dados Poplin-Minas-1830, organizado pela equipe do Núcleo de Pesquisas em História Econômica e Demográfica do Centro de Desenvolvimento e Planejamento Regional da Faculdade de Ciências Econômicas, Universidade Federal de Minas Gerais. Disponível em: <www.nphed.cedeplar.ufmg.br/poplin-minas-1830/>. Acesso em: 29 abr. 2021.

4 Arquivo Público Mineiro. Lista nominativas de habitantes de 1838/1840 para o termo de Baependi, Distrito de São José do Favacho. Disponível em: <www.nphed.cedeplar.ufmg.br/ poplin-minas-1830/>. Acesso em: 29 abr. 2021.

5 Curioso observar que, na publicação de uma coletânea de poemas intitulada 50 poemas de revolta (2017), embora dois poemas de Oswald de Andrade estejam inclusos ("O capoeira" e "Erro de português"), justamente o mais impactante, o poema "Levante", não faz parte da seleção.

6 Tudo indica que os autores se utilizaram das edições posteriores que substituíram a forma verbal "uivam" por "miavam".

7 Trata-se do projeto "Narrativas do tempo do cativeiro: memória oral e escravidão na comarca do Rio das Mortes", aprovado no Comitê de Ética em Pesquisa da Universidade Federal de São João del-Rei, cadastrado na Plataforma Brasil sob o Certificado de Apre- 
sentação de Apreciação Ética n. 94272518.6.0000.5151. 0 último trabalho de campo realizado foi em novembro de 2019. Em virtude da pandemia da covid-19, tivemos que interromper a pesquisa. 0 trabalho será retomado assim que as condições sanitárias permitirem. 0 projeto esteve vinculado ao Programa de Capacitação Docente/Projeto "Memória e comunidades de sentido: percursos historiográficos" (Programa Nacional de Cooperação Acadêmica) da Coordenação de Aperfeiçoamento de Pessoal de Nível Superior até 2020, desenvolvido em parceria com os Programas de Pós-Graduação em História da Universidade Federal Fluminense, Universidade Federal do Pará e Universidade Federal de São João del-Rei. 0 projeto também faz parte do Programa de Extensão da Universidade Federal de São João del-Rei desde 2018.

8 Entrevista realizada com o senhor Pedro Gonçalves da Rocha na zona rural de Cruzília no dia 30 de junho de 2017. Na época, ele contava com 63 anos.

9 Outra versão bastante comum na região é a de que o nome Cabeça Branca esteja associado às referidas paineiras quando florescem.

10 Entrevista realizada com o senhor Pedro Gonçalves da Rocha no local chamado Cabeça Branca, zona rural de Cruzília, no dia 9 de novembro de 2019.

11 Entrevista realizada com o senhor Pedro Gonçalves da Rocha, conforme descrito.

12 Entrevista realizada com o Senhor José Maria de Rezende em sua residência, na sede da fazenda Sobradinho, zona rural do município de São Tomé das Letras, no dia 14 de novembro de 2014.

13 Entrevista realizada com o senhor José Nélio Teodoro em sua residência, no distrito de Sobradinho, pertencente ao município de São Tomé das Letras, no dia 9 de novembro de 2019.

14 Entrevista realizada com o senhor José Nélio Teodoro, conforme descrito.

15 Carta de Mariana de Andrade Bueno aos seus primos May e Haroldo, datada de 27 de maio de 1978. Acervo original pertencente ao psicanalista e genealogista Dr. José Américo Junqueira de Mattos, que generosamente cedeu-me para a pesquisa.

160 processo do massacre da Bela Cruz. Anotações de Mariana de Andrade Bueno, conforme descrito.

17 Ana Francisca Junqueira casou-se com seu primo Antônio Rabelo de Carvalho (Mattos, 2004: 1001-1002).

18 Informação que foi possível de ser localizada por meio de uma nota de rodapé da dissertação de Lucila Reis Brioschi (1985, p. 187), a quem agradeço o envio da cópia do documento que the foi repassado pela genealogista Mariana de Andrade Bueno. 
19 Esta passagem também é citada no livro de José Alberto Pelúcio (1942: 229-231). 0 autor denominou a revolta como o Levante da Bela Cruz e construiu a sua narrativa com base no depoimento de um velho morador de Baependi, mas sem citar o nome do entrevistado. Outra breve menção à Revolta de Carrancas, também citada por José Alberto Pelúcio, pode ser encontrada na obra do escritor e poeta José Coelho Almeida Cousin. 0 literato tinha por hábito introduzir notas explicativas para os seus poemas referentes à história do Brasil. Em relação ao poema "Zumbi", na nota 11, citou brevemente os quilombos dos Palmares e os do Ambrósio e de Araxá, em Minas Gerais. Mas, já na década de 1930, não deixou de registrar o intrigante silenciamento da historiografia em relação a um evento tão traumático, mas de grande relevância para a história política e social da escravidão brasileira. "[...] das fazendas de Campo Alegre e Bella Cruz, em Baependy, no Sul de Minas. Nest[a]s, a revolta dos escravos, seguida de repressão igualmente cruenta que teve, constitui um dos mais abomináveis capítulos, ainda sem autor que o descrevesse, da história da escravidão no Brasil" (Cousin, 1931: 232).

20 Arquivo Histórico do Instituto do Patrimônio Histórico Nacional - Seção de São João del-Rei. Processo-crime de Insurreição (1833), cx. pc-29-01. Correspondência do juiz de paz de Baependi, Antônio Gomes Nogueira Freire, fls. 13.

21 /dem. Libelo acusatório, fl. 116v.

22 Idem. Interrogatório dos escravos José Carneiro Congo e José Mina (Campo Alegre) e Manoel Joaquim e Manoel das Caldas (Bela Cruz), fls. 130-131, 147, 153.

23 Idem. Auto de corpo de delito, fl. 10v.

24 Código Criminal do Império do Brasil. Coleção das Leis do Império do Brasil, 1830, p. 163 e 180. Disponível em: <https://www2.camara.leg.br/atividade-legislativa/legislacao/colecao-anual-de-leis/copy_of_colecao2.html> Acesso em: 29 abr. 2021.

Conflitos de interesse: nada a declarar.

Fonte de financiamento: Programa de Capacitação Docente da Coordenação de Aperfeiçoamento de Pessoal de Nível Superior (PROCAD/CAPES) e Programa de Extensão da Universidade Federal de São João del-Rei.

\section{REFERÊNCIAS BIBLIOGRÁFICAS}

ALBERTI, V. Manual de história oral. Rio de Janeiro: Fundação Getúlio Vargas, 2007.

ANDRADE, M. F. Rebelião escrava na comarca do Rio das Mortes, Minas Gerais: o caso Carrancas. Afro-Ásia, Salvador, n. 21/22, p. 45-82, 1998/1999. http://dx.doi.org/10.9771/aa.v0i21-22.20963. 
ANDRADE, M. F. Elites regionais e a formação do Estado imperial brasileiro: Minas Gerais - Campanha da Princesa (1799-1850). 2. ed. revista e atualizada. Belo Horizonte: Fino Traço, 2014.

ANDRADE, M. F. A pena de morte e a revolta dos escravos de Carrancas: a origem da "lei nefanda" (10 de junho de 1835). Tempo, Niterói, v. 23, n. 2, p. 264-289, 2017. https://doi.org/10.1590/TEM-1980$542 \times 2017 v 230204$.

ANDRADE, O. Um homem sem profissão: memórias e confissões - 1890-1919 — Sob as ordens de mamãe. 3. ed. Rio de Janeiro: Civilização Brasileira, 1976.

ANDRADE, O. Pau Brasil. 4. ed. São Paulo: Editora Globo, 2000.

BRIOSCHI, L. R. Família e genealogia: quatro gerações de uma grande família do sudeste brasileiro (17581850). 1985. Dissertação (Mestrado) - Universidade de São Paulo, São Paulo, 1985.

CAMPOS, A. A. Execuções na Colônia: a morte de Tiradentes e a cultura barroca. Tempo Brasileiro, Rio de Janeiro, n. 10, p. 141-167, 1992.

CANDIDO, A. Vários escritos. São Paulo: Duas Cidades, 1970.

CANDIDO, A. Oswáld, Oswaldo, Ôswald. Folha de São Paulo, São Paulo, 21 mar. 1982. Ilustrada, $7^{\circ}$ Caderno, p. 59. Disponivel em: <https://acervo.folha.com.br/leitor.do?numero=7987\&keyword=Antonio\%2CCandido\%2CAntonio\%2CCandido\&anchor $=4313907$ \&origem $=$ busca\&originURL=\&pd $=40 \mathrm{dbd} 5 \mathrm{e}-$ 88d357840aa01fb26a9ae3563>. Acesso em: 29 abr. 2021.

CHALHOUB, S. Machado de Assis historiador. São Paulo: Companhia das Letras, 2003.

CHALHOUB, S.; NEVES, M. S.; PEREIRA, L. A. M. (orgs.). História em cousas miúdas: capítulos de História Social da crônica no Brasil. Campinas: Editora da UNICAMP, 2005.

COUSIN, J. C. A. Itamonte (Epopéia Brasilista). Rio de Janeiro: Paulo Pongeti \& Cia, 1931.

FERREIRA, A. A fonte fecunda. In: PINSKY, C. B.; LUCA, T. R. O historiador e suas fontes. São Paulo: Contexto, 2012. p. 61-92.

FONSECA, M. A. Taí: é ou não é - Cancioneiro Pau Brasil. Literatura e Sociedade, São Paulo, v. 9, n. 7, p. 120-145, 2004. https://doi.org/10.11606/issn.2237-1184.v0i7p120-145.

FONSECA, M. A. Oswald de Andrade: biografia. 2. ed. Rio de Janeiro: Editora Globo, 2007.

GAGNEBIN, J. M. Lembrar escrever esquecer. São Paulo: Editora 34, 2006.

GINZBURG, C. O fio e os rastros: verdadeiro, falso, fictício. Trad. Rosa Freyre d'Aguiar e Eduardo Brandão. São Paulo: Companhia das Letras, 2007.

GUIMARÃES, J. As três ilhoas. São Paulo: Imprensa Latina, 1990. v. 1.

HALBWACHS, M. A memória coletiva. São Paulo: Vértice; Revista dos Tribunais, 1990.

LE GOFF, J. História e memória. Trad. Bernardo Leitão et al. 5. ed. Campinas: Editora da UNICAMP, 2003.

LOUREIRO, C.; LIMA, A. F. S. A reinvenção da história e de memórias acerca da colonização brasileira em Pau Brasil: um estudo crítico acerca da recriação da pluralidade de identidades brasileiras pelos modernistas. Entrelaces, Fortaleza, ano VI, n. 7, p. 124-142, jan.-jun. 2016. 
MAHONY, M. A. Um passado para justificar o presente: memória coletiva, representação histórica e dominação política na região cacaueira da Bahia. Cadernos de Ciências Humanas - Especiaria, Florianópolis, v. 10, n. 18, p. 737-793, dez. 2007.

MANFIO, D. Z. Poesias reunidas de Oswald de Andrade: estudos para uma edição crítica. Revista de Letras, São Paulo, v. 30, p. 43-51, 1990.

MARINHO, J. A. História do movimento político que no ano de 1842 teve lugar na província de Minas Gerais. Rio de Janeiro: Typografia de J. E. S. Cabral, 1844.

MATTOS, J. A. J. Família Junqueira: sua história e genealogia. Rio de Janeiro: Família Junqueira, 2004.

MAUAD, A. M.; ALMEIDA, J. R.; SANTHIAGO, R. (orgs.). História Pública no Brasil: sentidos e itinerários. São Paulo: Letra e Voz, 2016.

MEIHY, J. C. S. B.; HOLANDA, F. História oral: como fazer, como pensar. São Paulo: Contexto, 2007.

PARRON, T. P. A política da escravidão na era da liberdade: Estados Unidos, Brasil e Cuba, 1878-1846. Tese (Doutorado em História) - Universidade de São Paulo, São Paulo, 2015.

PELÚCIO, J. A. Baependí. São Paulo: Gráfica Paulista, 1942.

PIROLA, R. Escravos e rebeldes nos tribunais do Império: uma história social da lei de 10 de junho de 1835. Rio de Janeiro: Arquivo Nacional, 2015.

POLLAK, M. Memória, esquecimento, silêncio. Estudos Históricos, Rio de Janeiro, v. 2, n. 3, p. 3-15, 1989.

POLLAK, M. Memória e identidade social. Estudos Históricos, Rio de Janeiro, v. 5, n. 10, p. 200-212, 1992.

PORTELLI, A. Ensaios de história oral. São Paulo: Letra e Voz, 2010.

RIBEIRO, J. L. No meio das galinhas as baratas não têm razão: a lei de 10 de junho de 1835 — os escravos e a pena de morte no Império do Brasil, 1822-1889. Rio de Janeiro: Renovar, 2005.

RIOS, A. L.; MATTOS, H. Memória do cativeiro. Rio de Janeiro: Civilização Brasileira, 2005.

RODRIGUES, J. L. Serra dos Pretos: trajetórias de famílias egressas do cativeiro no pós-abolição (Sul de Minas Gerais, 1888-1950). Afro-Ásia, Salvador, n. 50, p. 171-193, 2014. http://dx.doi.org/10.9771/ aa.v0i50.21349.

SEVCENKO, N. Literatura como missão: tensões sociais e criação cultural na Primeira República. São Paulo: Brasiliense, 1982.

TROUILLOT, M.-R. Silenciando o passado: poder e a produção da história. Trad. Sebastião Nascimento. Curitiba: Huya, 2016.

VÁRIOS autores. 50 poemas de revolta. São Paulo: Companhia das Letras, 2017.

WEIMER, R. A. "O meu avô me contava": dinâmicas de circulação da memória do cativeiro entre descendentes de escravos. Osório, século XX. História Oral, Rio de Janeiro, v. 13, n. 2, , p. 65-87, jul.-dez. 2010. https:// doi.org/10.51880/ho.v13i2.140. 